\title{
POTENSI PEMANFAATAN LIMBAH PII QUARY SEBAGAI PENGGANTI AGREGAT HALUS BETON
}

\author{
Wennie Mandela $^{(1)}$, A. Didik Setyo Purwantoro ${ }^{(2)}$ \\ ${ }^{I}$ Dosen program studi teknik sipil universitas muhammadiyah sorong, Jl.Pendidikan No.27, Klabulu, \\ Malaimsimsa, Kota Sorong, Papua Barat 98412, Telp : (0951) 322383 Fax : (0951) 326162, email: \\ wennie.mandela14@gmail.com
}

\begin{abstract}
ABSTRAK
Fakta di beberapa quary pasir wilayah Sorong Raya, kadar lumpurnya masih cukup tinggi yaitu kisaran $8 \%$ - $19 \%$ dengan mutu beton yang didapatkan maksimal K-200. Dalam upaya mencari alternatif material pasir lokal tersebut, teridentifikasi ada limbah dari perusahaan pengolah tambang batu pecah yang ada di Kota Sorong yaitu PT Pro Intertech Indonesia (PII QUARY).Tujuan penelitian ini adalah untuk menganalisis mutu beton rata-rata yang dihasilkan dari uji laboratorium atas benda uji beton yang memakai limbah PII Quary dan untuk mengidentifikasi potensi serta kelayakan limbah PII Quary apakah dapat dijadikan alternatif pengganti agregat halus beton Penelitian ini merupakan penelitian eksperimental yang dilakukan di laboratorium Teknologi Beton Teknik Sipil Universitas Muhammadiyah Sorong. Penelitian yang menggunakan jenis material limbah dari PII Quary berupa pasir batu. Sampel yang diambil akan dicampur dengan agregat kasar, semen dan air untuk kemudian diketahui karakteristik mutu beton yang dihasilkan. Hasil penelitian didapatkan uji kuat tekan rata-rata silinder beton umur 28 hari sebesar 17,5 MPa belum mencapai mutu beton yang ditargetkan yaitu $25 \mathrm{MPa}$. Limbah batu pecah PII Quary disimpulkan dapat dijadikan sebagai alternatif bahan pengganti agregat halus beton. Akan tetapi, mutu beton yang dihasilkan hanya memenuhi mutu beton kelas 1 yang digunakan bukan untuk pekerjaan struktur.
\end{abstract}

Kata kunci: Limbah quary, mutu beton, agregat halus

\section{PENDAHULUAN}

Dengan kondisi kualitas pasir lokal di wilayah Sorong Raya yang mengandung kadar lumpur rata-rata di atas ambang batas yang diijinkan sehingga mutu betonnya rendah, maka perlu dicari alternatif bahan / material pengganti. Selama ini yang berlaku dalam beberapa pekerjaan konstruksi di wilayah Sorong Raya, jika menginginkan kualitas beton yang baik apalagi beton mutu tinggi, maka banyak mendatangkan material pasir dari luar wilayah seperti dari Tobelo, Palu dan dari wilayah lain yang kualitas pasir nya lebih bagus. Hal ini pastilah akan menaikkan biaya konstruksi secara signifikan, walaupun akan tetap diambil langkah ini bagi yang menginginkan kualitas pekerjaan betonnya tercapai pada level kualitas bagus sampai beton mutu tinggi. Untuk pasir dari Tobelo, menurut data sampel yang pernah diuji di Lab Beton Teknik Sipil Universitas Muhammadiyah Sorong tahun 2017 didapatkan kadar lumpurnya 2,6\% dan mutu beton bisa mencapai K-350 sampai K-400. Pengujian beton dengan agregat halus dari Tobelo ini dikerjakan dalam kegiatan kerjasama dengan PT. WIKA yang sedang menangani pekerjaan konstruksi dermaga di Kabupaten Sorong.

Dalam upaya mencari alternatif material pasir lokal tersebut, teridentifikasi ada limbah dari perusahaan pengolah tambang batu pecah yang ada di Kota Sorong yaitu PT Pro Intertech Indonesia (PII QUARY). Limbah yang dimaksud adalah pasir batu (sirtu) yang merupakan sisa dari proses pemecahan batu menjadi agregat kasar (kerikil) dan 
batu koral. Limbah dari PII QUARY tersebut selama ini dikonsumsi masyarakat jasa konstruksi untuk material lapis pondasi atas pada pekerjaan jalan. Informasi dari pihak PII QUARY, didapat bahwa limbah tersebut dijual dengan harga Rp 150.000,- per kubik on site. Sedangkan harga satuan agregat halus (pasir cor) sesuai dengan basic price bahan bangunan yang dirilis oleh PU Kota Sorong adalah Rp 180.000,- per kubik on site. Dari sisi harga on site kedua material tidak ada perbedaan yang signifikan, akan tetapi dari sisi kualitas mutu beton yang dihasilkan dari pasir lokal tersebut cukup rendah mengingat kadar lumpurnya yang cukup tinggi. Sehingga dari uji laboratorium direkomendasikan untuk melakukan pencucian ulang pasir lokal tersebut. Kenapa disebut harus dicuci ulang, diinformasikan bahwa untuk wilayah Sorong Raya sumber material pasir itu mayoritas berasal dari proses pencucian tanah berpasir perbukitan di belakang Kota Sorong yang di cutting untuk diproses menjadi pasir, baik pasir plesterpasir pasang maupun pasir cor. Itupun kadar lumpur yang dihasilkan dari proses pencucian tanah berpasir masih cukup tinggi, sehingga menyebabkan tidak optimalnya kualitas mutu beton yang dihasilkan.

Di sisi lain, aktifitas cutting perbukitan dan pencucian pasir tersebut berpotensi besar untuk merusak lingkungan. Atas beberapa hal tersebut di atas, maka limbah PII QUARY layak untuk diuji coba melalui serangkaian penelitian di laboratorium terkait mutu beton yang bisa dihasilkan, sehingga nantinya akan ada rekomendasi teknis terkait kelayakan limbah PII QUARY tersebut sebagai alternatif pengganti agregat halus dalam pekerjaan beton di wilayah Sorong Raya.

\section{Tujuan penelitian}

Tujuan dari penelitian ini adalah untuk :

1. Mengidentifikasi potensi dan kelayakan limbah PII Quary untuk dijadikan alternatif pengganti agregat halus beton.

2. Menganalisis mutu beton rata-rata yang bisa dihasilkan dari uji laboratorium atas benda uji beton yang memakai limbah PII Quary untuk dijadikan alternatif pengganti agregat halus beton.

\section{Batasan masalah}

Dengan mempertimbangkan luasnya permasalahan yang timbul serta keterbatasan waktu dan kemampuan, maka perlu adanya batasan masalah agar memperjelas dalam menganalisa permasalahan.

Ruang Lingkup dan materi yang akan dianalisa terpusat pada batasan-batasan sebagai berikut:

1. Material yang akan diuji adalah agregat halus Limbah Batu Pecah PII.

2. Semen yang digunakan adalah Tipe semen PPC (semen Gresik).

3. Agregat kasar yang digunakan berasal dari PT.PII SAOKA

4. Air yang digunakan adalah air dari instalasi air bersih laboratorium Teknik Sipil, Fakultas Teknik Universitas Muhammadiyah Sorong

5. Mutu beton yang direncanakan $25 \mathrm{Mpa}$ (untuk beton umur 3 hari, 7 hari dan 28 hari)

6. Tata cara pembuatan rencana campuran beton normal berdasarkan SNI 03-28342000

7. Sampel berbentuk silinder 
8. Jumlah sampel Limbah PT PII berjumlah 9 sampel terdiri dari umur 3,7, dan 28 hari.

\section{Tinjauan pustaka}

Peneliti menemukan beberapa karya ilmiah dari beberapa jurnal yang sudah ada yang akan peneliti gunakan sebagai acuan dalam meneliti, antara lain :

1. Arif, (2015) menyatakan dalam hasil penelitiannya bahwa (a) kadar lumpur agregat halus quary Sorong sebesar 7,4\% dengan nilai kuat tekan beton sebesar $13 \mathrm{MPa}$, (b) kadar lumpur agregat halus quary Sorong sebesar 4,8\% dengan nilai kuat tekan beton sebesar $14 \mathrm{MPa}$.

2. Pebryansyah, (2016) menyatakan dalam hasil penelitiannya antara lain : (a) kadar lumpur pasir dari quary KM 14 Kota Sorong setelah dicuci selama 4 jam bisa mencapai 3\%, (b) Dari hasil penelitian kuat tekan pada beton 7 hari dan 28 hari, terlihat perbandingan kekuatan beton akibat abu batu menyebabkan penurunan pada mutu beton, pada beton 7 hari kekuatan tekan beton normal sebesar $15 \mathrm{Mpa}$ mengalami penurunan akibat pengaruh subtitusi abu batu, abu batu sebesar $15 \%$ mengalami penurunan sebesar $3 \mathrm{Mpa}$, subtitusi 25\% mengalami penurunan sebesar $5 \mathrm{Mpa}$, dan pada subtitusi 50\% mengalami penurunan hingga $11 \mathrm{MPa}$.

3. Pesireron, (2016) dalam hasil penelitiannya menyatakan bahwa : (a) kadar lumpur pasir dari quary KM 14 Kota Sorong setelah dicuci selama 4 jam mencapai 4\%, , (b) besaran mutu beton yang dihasilkan adalah 15,11 $\mathrm{MPa}$, (c) pengaruh dari penambahan lumpur pada agregat halus campuran beton umur 7 hari adalah penurunan sebesar 7,35\% untuk variasi subtitusi lumpur 5\%, penurunan sebesar $20,59 \%$ untuk variasi subtitusi lumpur $10 \%$, dan penurunan sebesar $27,21 \%$ untuk variasi subtitusi lumpur $15 \%$, (d) pengaruh dari penambahan lumpur pada agregat halus campuran beton umur 28 hari adalah penurunan sebesar 19,17\% untuk variasi subtitusi lumpur 5\%, penurunan sebesar 30,72\% untuk variasi subtitusi lumpur $10 \%$, dan penurunan sebesar 36,95 \% untuk variasi subtitusi lumpur $15 \%$.

\section{Kuat tekan beton}

Kuat tekan beton yang diisyaratkan adalah kuat tekan beton yang ditetapkan oleh perencana struktur (benda uji berbentuk silinder diameter $150 \mathrm{~mm}$ dan tinggi $300 \mathrm{~mm}$ ), dipakai dalam perencanaan struktur beton, dinyatakan dalam Mega Paskal atau Mpa.

Nilai kuat tekan beton didapatkan melalui tata cara pengujian standar, menggunakan mesin uji dengan cara memberikan beban tekan bertingkat dengan kecepatan peningkatan beban tertentu atas benda uji silinder beton (diameter $150 \mathrm{~mm}$, tinggi 300 $\mathrm{mm}$ ) sampai hancur. Tata cara pengujian yang umumnya dipakai adalah standar ASTM (American Sosiety for Testing Material), C39-86. Kuat tekan masing-masing benda uji ditentukan oleh tegangan tekan tertinggi (f'c) yang dicapai benda uji umur 28 hari akibat beban tekan selama percobaan. Faktor-faktor yang sangat mempengaruhi kekuatan beton antara lain faktor air semen, umur beton, jenis semen, jumlah semen, dan sifat agregat.

\section{Kadar Lumpur}

Lumpur yang terdapat pada permukaan agregat dapat mengganggu ikatan antara agregat dengan pasta semen. Karena ikatan ini sangat penting dalam adukan beton, yang berpengaruh terhadap kekuatan dan daya tahan beton. Jika dalam agregat mengandung 
banyak Lumpur akan menambah permukaan agregat sehingga keperluan air untuk membasahi semua permukaan butiran dalam campuran meningkat. Ini mengakibatkan kekuatan dan ketahanan beton dapat menurun. Lumpur pada pasir berpengaruh pada adukan beton. Karena lumpur mempunyai sifat-sifat seperti berikut (a) mengurangi ikatan dengan pasta semen, (b) melekat erat pada butir pasir dan tidak terlepas sewaktu pengadukan beton, (c) merupakan suspensi dalam campuran air dan dapat terbawa ke muka atau lapisan dekat muka, (d) jika konsentrasi besar dapat menghasilkan beton berkualitas rendah, (e) bila merata pada seluruh campuran , dapat mengurangi bleeding beton dan lumpur merupakan kelas bahan-bahan yang berbutir sangat halus (kohesif).

\section{Faktor Air Semen}

Faktor air semen adalah perbandingan banyaknya air bebas kecuali yang terserap oleh agregat, terhadap banyaknya semen dalam adukan beton. Faktor air semen (FAS) merupakan salah satu faktor yang sangat penting. Peningkatan jumlah air akan meningkatkan kemudahan pengerjaan dan pemadatan, tetapi akan mereduksi kekuatan dan menimbulkan segregasi dan bleeding. Pada umumnya tiap partikel membutuhkan air supaya plastis sehingga dapat dikerjakan. Umumnya nilai faktor air semen ( FAS ) minimum yang diberikan sekitar 0,4 dan maksimum 0,65. Rata-rata ketebalan lapisan yang memisahkan antar partikel dalam beton sangat bergantung pada faktor air semen yang digunakan dan kehalusan butir semennya.

\section{Porositas}

Tingkat keporositasan pada beton ditentukan oleh jumlah pori atau rongga udara yang terkandung di dalamnya. Sedangkan jumlah rongga udara yang terdapat dalam beton sangat berpengaruh terhadap kuat tekan beton tersebut. Semakin banyak rongga udara yang terkandung dalam beton, maka akan semakin rendah nilai kuat tekan beton tersebut.

\section{METODE PENELITIAN}

Penelitian ini dilaksanakan di laboratorium Teknik Sipil Fakultas Teknik Universitas Muhammadiyah Sorong, dengan mengambil lokasi sampel penelitian untuk material agregat halus yaitu Limbah batu pecah PT.PII SAOKA.

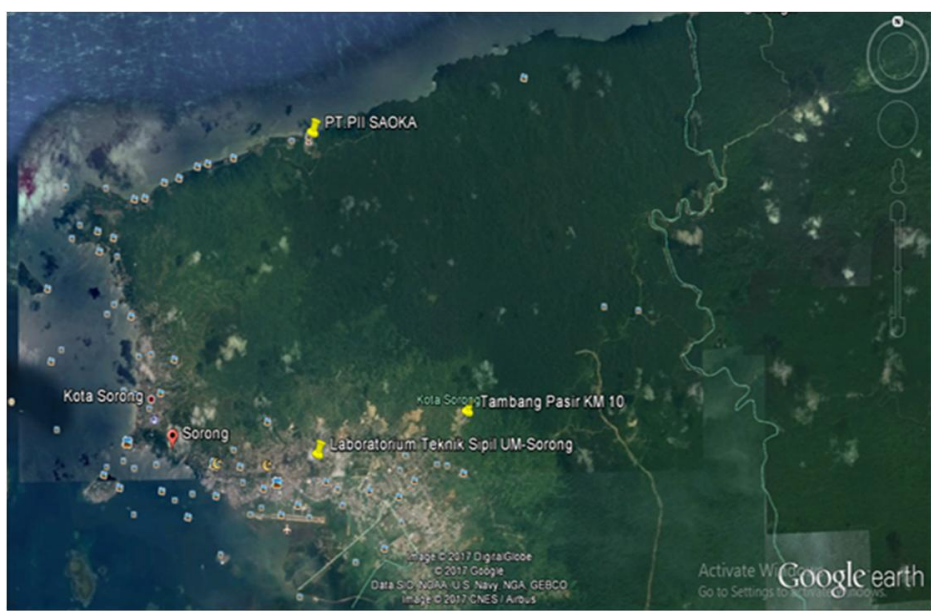

Gambar 1. Lokasi Pengambilan Material danTempat Penelitian 
Bahan yang digunakan pada penelitian ini terdiri dari: semen tipe PPC, Agregat Kasar, Agregat Halus (berasal dari quarry limbah batu pecah PT.PII SAOKA), dan air. Limbah batu pecah PII yang diambil yaitu limbah batu pecah sekunder berupa material dari hasil pemecahan batu kedua dengan menggunakan mesin crusher melalui beberapa tahapan saringan. Limbah sekunder ini berupa campuran tanah, kerikil, dan pasir.

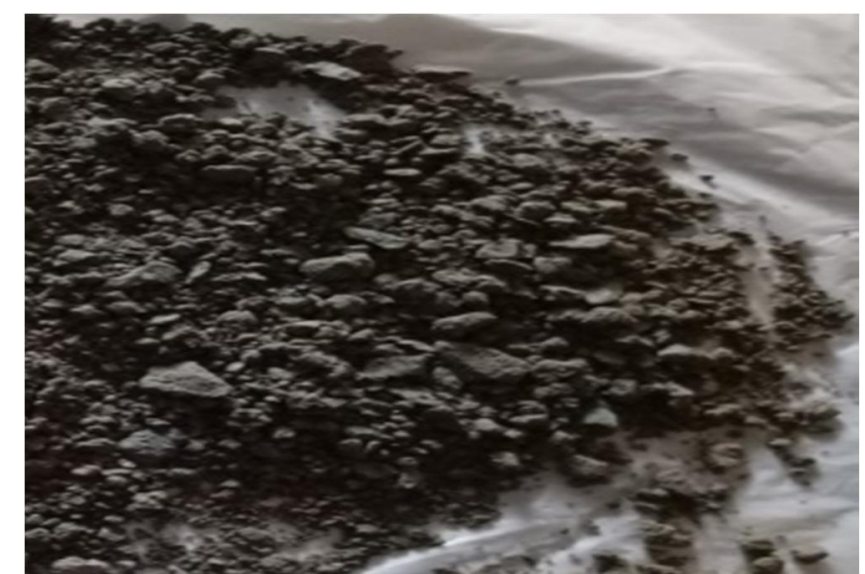

Gambar 2. Limbah sekunder batu pecah PII quary

Pada penelitian ini dilakukan beberapa jenis pengujian diantaranya adalah pengujian karakteristik agregat halus dan agregat kasar, perencanaan campuran beton (mix desain), pembuatan benda uji silinder beton, pengujian slump, perawatan benda uji, dan pengujian kuat tekan beton.

Pengujian karakteristik agregat halus dan agregat kasar yaitu :

a. Pemeriksaan berat isi padat agregat halus

b. Pemeriksaan berat isi gembur agregat halus

c. Pemeriksaan Modulus Halus Butir (MHB) agregat halus

d. Pemeriksaan berat jenis dan kadar air agregat halus

e. Pemeriksaan agregat halus lewat ayakan No.200

f. Pemeriksaan berat isi padat agregat kasar

g. Pemeriksaan berat isi gembur agregat kasar

h. Pemeriksaan Modulus Halus Butir (MHB)agregat kasar

i. Pemeriksaan berat jenis dan kadar air agregat kasar.

\section{HASIL DAN PEMBAHASAN}

\section{Pengujian material}

Hasil Pengujian karakteristik agregat kasar dan agregat halus limbah batu pecah PII quary.

Dari tabel 1 hasil pengujian agregat didapatkan nilai kadar lumpur agregat halus limbah batu pecah PII 19,4\%, modulus halus butir 4,886\%, berat jenis (SSD) 2,645 $\mathrm{gr} / \mathrm{cm}^{3}$, penyerapan air sebesar $13,8 \%$, berat isi padat $1,719 \mathrm{gr} / \mathrm{cm}^{3}$ dan berat isi gembur 1,537 $\mathrm{gr} / \mathrm{cm}^{3}$. Untuk agregar kasar batu pecah didapatkan modulus halus butir 5,46\%, berat jenis (SSD) $3,27 \mathrm{gr} / \mathrm{cm}^{3}$, penyerapan air $5,21 \%$, berat isi padat $1,507 \mathrm{gr} / \mathrm{cm}^{3}$ dan berat isi gembur $1,322 \mathrm{gr} / \mathrm{cm}^{3}$. 
Tabel 1. Hasil pengujian agregat

\begin{tabular}{lll}
\hline Penelitian & Ak. Batu pecah & Ah.Limbah batu pecah PT.PII \\
\hline Kadar lumpur dalam pasir (\%) & - & $19,4 \%$ \\
Modulus halus butir & $5,46 \%$ & $4,886 \%$ \\
Berat jenis (SSD) & $3,27 \mathrm{gr} / \mathrm{cm}^{3}$ & $2,645 \mathrm{gr} / \mathrm{cm}^{3}$ \\
Penyerapan air (\%) & $5,21 \%$ & $13,8 \%$ \\
Berat isi padat & $1,507 \mathrm{gr} / \mathrm{cm}^{3}$ & $1,719 \mathrm{gr} / \mathrm{cm}^{3}$ \\
Berat isi gembur & $1,322 \mathrm{gr} / \mathrm{cm}^{3}$ & $1,537 \mathrm{gr} / \mathrm{cm}^{3}$ \\
\hline
\end{tabular}

Tabel 2. Kuat Tekan Silinder Beton Umur 3 Hari

\begin{tabular}{|c|c|c|c|c|c|c|c|}
\hline No & Benda uji & $\mathrm{fc}$ Mpa & fcr Mpa & Luas $\left(\mathrm{mm}^{2}\right)$ & $\begin{array}{c}\text { Beban } \\
\text { Maksimum }\end{array}$ & $\begin{array}{c}\text { fc hasil üi } \\
\text { (Mpa) }\end{array}$ & Rata - rata \\
\hline 1 & Silinder & 25 & 35 & 176.785 & 230 & 13,0218 & \multirow{2}{*}{$13,3007 \mathrm{Mpa}$} \\
\hline 2 & Silinder & 25 & 35 & 176.785 & 230 & 13,0218 & \\
\hline 3 & Silinder & 25 & 35 & 176.785 & 245 & 13,8586 & \\
\hline
\end{tabular}

Tabel 3. Kuat Tekan Silinder Beton Umur 7 Hari

\begin{tabular}{|c|c|c|c|c|c|c|c|}
\hline No & Benda uji & fc Mpa & fcr Mpa & Luas $\left(\mathrm{mm}^{2}\right)$ & \begin{tabular}{|c|} 
Beban \\
Maksimm
\end{tabular} & $\begin{array}{c}f c \text { hasil uji } \\
\text { (Mpa) }\end{array}$ & Rata - rata \\
\hline 1 & Sïnder & 25 & 35 & 176.785 & 240 & 13,5758 & \multirow{3}{*}{$13,7643 \mathrm{Mpa}$} \\
\hline 2 & Sünder & 25 & 35 & 176.785 & 245 & 13,8586 & \\
\hline 3 & Sïlinder & 25 & 35 & 176.785 & 245 & 13,8586 & \\
\hline
\end{tabular}

Tabel 4. Kuat Tekan Silinder Beton Umur 28 Hari

\begin{tabular}{|c|c|c|c|c|c|c|c|}
\hline No & Benda uji & fc Mpa & fcrMpa & Luas $\left(\mathrm{mm}^{2}\right)^{2}$ & $\begin{array}{c}\text { Beban } \\
\text { Maksimmm }\end{array}$ & $\begin{array}{c}\text { fc hasil uji } \\
\text { (Mpa) }\end{array}$ & Rata - rata \\
\hline 1 & Silinder & 25 & 35 & 176.785 & 280 & 15,8384 & \multirow{2}{*}{$1,5354 \mathrm{Mpa}$} \\
\hline 2 & Silinder & 25 & 35 & 176.785 & 325 & 18,3839 & 175 \\
\hline 3 & Silinder & 25 & 35 & 176.785 & 325 & 18,3839 & \\
\hline
\end{tabular}

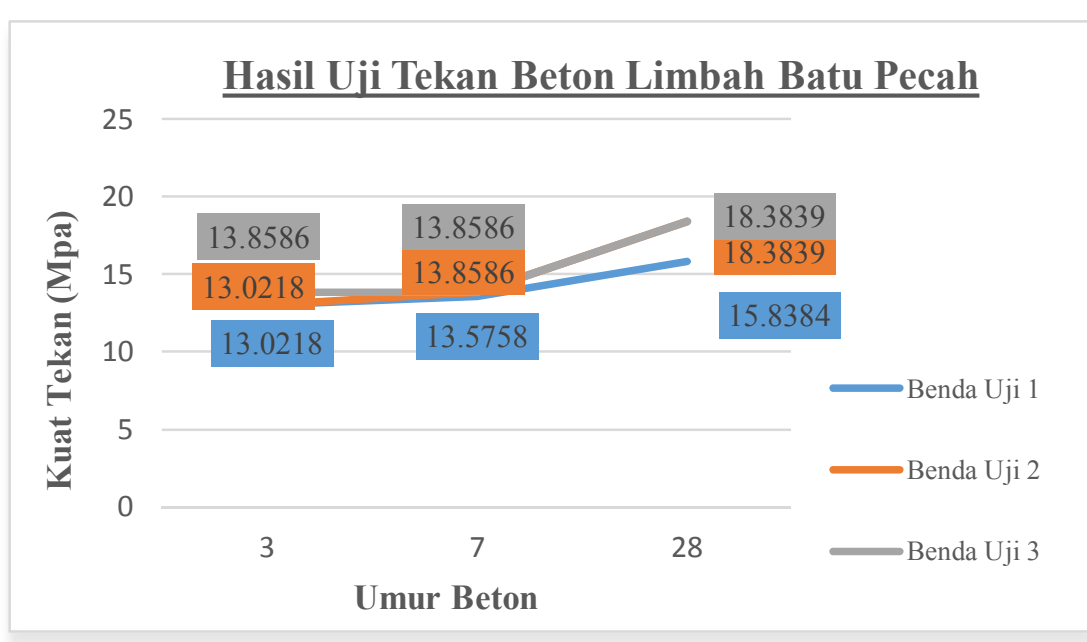

Gambar 3. Grafik hubungan kuat tekan limbah batu pecah terhadap umur beton 
Berdasarkan gambar 3, grafik menunjukkan hasil kuat tekan beton limbah batu pecah, dengan beberapa sampel dan diuji pada umur 3,7,dan 28 hari. Dalam grafik, Sampel benda uji 1 pada umur 3 hari mempunyai kuat tekan 13,0218 MPa,7 hari diperoleh 13,5758 MPa,dan 28 hari diperoleh 15,8384 MPa. Sampel benda uji 2 pada umur 3 hari mempunyai kuat tekan 13,0218 MPa,7 hari diperoleh 13, $8586 \mathrm{MPa}$,dan 28 hari diperoleh 18,3839 $\mathrm{MPa}$. Dan Sampel benda uji 3 pada umur 3 hari mempunyai kuat tekan 13,8586 MPa,7 hari diperoleh 13,8586 MPa,dan 28 hari diperoleh 18,3839 $\mathrm{MPa}$.

\section{Hasil Kuat Tekan Beton Rata-rata Limbah batu pecah}

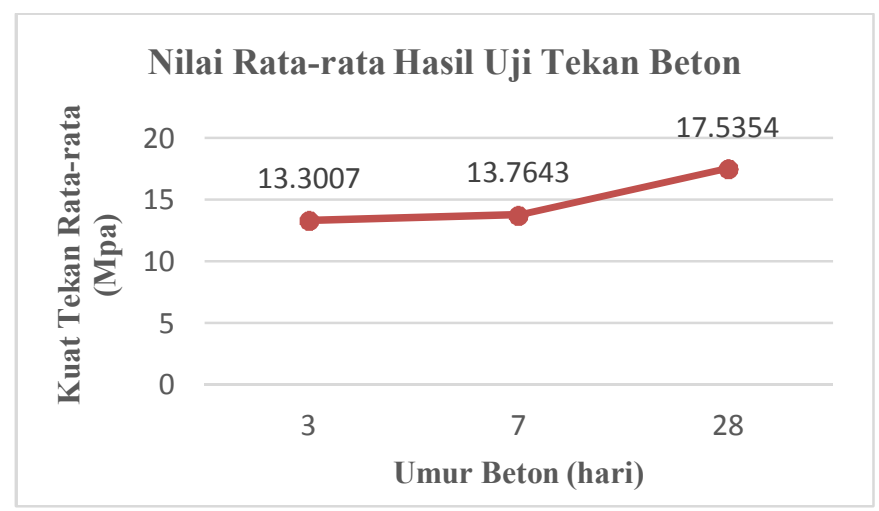

Gambar 4. Grafik kuat tekan beton rata-rata limbah batu pecah

Berdasarkan gambar 4 di atas, hasil uji tekan beton limbah batu pecah menunjukkan kuat tekan rata - rata beton yang dihasilkan mulai dari umur 3 hari mempunyai kuat tekan rata-rata 13,3007 $\mathrm{MPa}, 7$ hari mempunyai kuat tekan rata-rata 13,7643 $\mathrm{MPa}$ dan 28 hari mempunyai kuat tekan rata-rata 17,5354 Mpa. Dari gambar 3 dapat dilihat bahwa semakin bertambahnya umur beton maka semakin meningkat atau semakin besar kuat tekan betonnya. Hal ini terjadi karena proses pengikatan oleh semen dan air terhadap agregat halus limbah batu pecah dan kerikil berjalan dengan baik.

Apabila dilihat dari grafik di atas, hasil penelitian kuat tekan beton pada setiap umur beton mengalami kenaikan kuat tekan beton sesuai dengan lamanya masa perawatan beton. Akan tetapi, dari tabel kuat tekan silinder beton limbah batu pecah umur 3 hari, 7 hari dan 28 hari, nilai kuat tekan beton yang dihasilkan tidak memenuhi kuat tekan beton yang direncanakan. Salah satu faktor penyebabnya yaitu pada kandungan lumpur material limbah batu pecah yaitu sebesar 19,4\% dimana berdasarkan hasil penelitian tersebut kandungan lumpur agregat halus dari limbah batu pecah tidak memenuhi syarat yang ditetapkan SNI yaitu kandungan lumpur maksimum $5 \%$ untuk agregat halus. Namun penelitian ini bertujuan untuk mengetahui karakteristik agregat dan kuat tekan beton dari agregat halus limbah batu pecah sehingga penelitian tetap dilanjutkan.

Selain itu faktor lain yang menyebabkan tidak terpenuhinya kuat tekan beton yang direncanakan terletak pada penyerapan air dari material yaitu penyerapan air $13.8 \%$ hasil dari Limbah batu pecah. Seperti kita ketahui air yang terkandung di dalam agregat ini akan mempengaruhi jumlah air yang diperlukan di dalam pencampuran (mix). Agregat yang basah akan membuat campuran lebih basah dan akan meningkatkan faktor air semen, sebaliknya agregat yang kering akan menyerap air dan menurunkan kelecekan campuran. 
Dari hasil penelitian kuat tekan rata-rata silinder beton limbah batu pecah PII Quary dapat dijadikan alternatif pengganti agregat halus beton. Akan tetapi mutu beton yang dihasilkan hanya memenuhi mutu beton kelas 1 yang digunakan bukan untuk pekerjaan struktur

\section{KESIMPULAN}

Berdasarkan hasil penelitian yang telah dilaksanakan, dapat menyimpulkan bahwa:

1. Hasil identifikasi potensi dan kelayakan limbah batu pecah PII Quary untuk dijadikan alternatif pengganti agregat halus beton yaitu :

a. Hasil pengujian agregat halus limbah batu pecah mengandung kandungan lumpur sebesar 19,4 \%.(Material Tidak Dicuci )

b. Dari analisa saringan yang dilaksanakan Modulus Halus Butir (MHB) agregat halus limbah batu pecah adalah $4,8865 \mathrm{gr} / \mathrm{cm}^{3}$.

c. Dari hasil nilai berat jenis untuk kondisi jenuh kering permukaan agregat halus limbah batu pecah sebesar $2,645 \mathrm{gr} / \mathrm{cm}^{3}$.

d. Besarnya penyerapan air agregat Limbah Batu Pecah yaitu 13,8\%

2. Hasil pengujian kuat tekan rata-rata beton dengan agregat halus limbah batu pecah PII Quary :

a. Umur 3 hari $=13,3007 \mathrm{Mpa}$

b. Umur 7 hari $=13,7643 \mathrm{Mpa}$

c. Umur 28 hari $=17,5354 \mathrm{Mpa}$

Dari hasil laboratorium uji kuat tekan rata-rata silinder beton dengan menggunakan agregat halus limbah batu pecah PII Quary belum mencapai mutu beton yang ditargetkan f'c 25 mpa. Limbah batu pecah PII Quary yang digunakan sebagai bahan pengganti agregat halus pada penelitian ini, disimpulkan dapat dijadikan sebagai alternatif bahan pengganti agregat halus beton. Akan tetapi, mutu beton yang dihasilkan hanya memenuhi mutu beton kelas 1 yang digunakan bukan untuk pekerjaan struktur.

\section{UCAPAN TERIMAKASIH}

Ucapan terima kasih kepada Direktorat Riset dan Pengabdian Masyaraka Direktorat Jenderal Penguatan Riset dan Pengembangan Kementrian Riset, Teknologi dan Pendidikan Tinggi yang telah membiayai penelitian ini dengan topik Potensi Pemanfaatan Limbah PII Quary Sebagai Pengganti Agregat Halus Beton.

\section{DAFTAR PUSTAKA}

[1] Arif, M., 2015. Analisa Perbandingan Kualitas Beton dengan Agregat Halus Quary Sungai Maruni Manokwari dan KM 10 Kota Sorong. Teknik Sipil Universitas Muhammadiyah Sorong.

[2] Pebryansyah, 2016. Pengaruh Subtitusi Semen dengan Abu Batu pada Kuat Tekan Beton. Teknik Sipil Universitas Muhammadiyah Sorong.

[3] Pesireron, G., N., 2016. Analisa Pengaruh Kandungan Lumpur Pada Agregat Halus Terhadap Mutu Beton. Teknik Sipil Universitas Muhammadiyah Sorong.

[4] Badan Standar Nasional, "Tentang Tata Cara Pembuatan Rencana Campuran Beton Normal”, SNI 03 2834:2000. Jakarta, 2000. 